\title{
Demystifying ophidism: bridging school and society to develop educational resources
}

\author{
Mikaelle Kaline Bezerra da Costa \\ Magnólia Fernandes Florêncio Araújo \\ Rita Campos \\ Eliza Maria Xavier Freire
}

I Post-Graduation Program in Development and Environment, Federal University of Rio Grande do Norte, Natal, Rio Grande do Norte, Brazil.

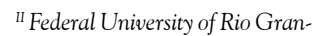
de do Norte, Natal, Rio Grande do Norte, Brazil.

D ${ }^{I I I}$ Centre for Social Studies-University of Coimbra, Coimbra, Portugal.

IV Department of Botanic and Zoology. Federal University of Rio Grande do Norte, Natal, Rio Grande do Norte, Brazil.

\begin{abstract}
Schools are inseparable from communities, and learning should empower students and the community to think and act on issues that affect them. In the semiarid Brazilian Caatinga, snake bites are a health issue. Negative beliefs and poor knowledge about snakes seed harmful attitudes, leading to high frequencies of snake bites and problems to conservation of these animals. Thus, we question whether the development of scientific and environmental education content using teaching strategies that valued the prior knowledge of local communities and context-related information could help to overcome beliefs and reduce accidents. The evaluation of this content showed positive changes in the perception of snakes and in the acquisition of new knowledge about these animals, and of prevention and post-bite actions, indicating that the adopted strategy supports science learning, contributing to both public health and conservation of snakes.
\end{abstract}

Keywords: Snake bites, perception, educational resources, environmental education, context-based learning.

São Paulo. Vol. 24, 2021

Original Article

DOI: http://dx.doi.org/10.1590/1809-4422asoc20200148r1vu2021L2AO 


\section{Introduction}

Human-snake conflicts are a concern in many areas of the planet for both public health and biodiversity conservation (MENDONÇA et al., 2014). Worldwide, snakes are generally considered beneficial to humans because of their role in the control of synanthropic rodents, particularly in areas of food cultivation and trade (NOGAN; HARUNA, 2015). Some human societies use snake products and sub-products as food sources, to produce artefacts, in traditional medicine or even as pets (COSTA-NETO, 2000; MOURA et al., 2010; ALVES et al., 2014). The venom extracted from some snake species has high pharmacological potential (HESS; SQUAIELLA-BAPTISTÃO, 2012; SANTOS et al., 2017). However, myths, fables and biblical texts shared by societies in their cultures have historically contributed to build a negative image of snakes. This distorted perception is primarily related to a lack of knowledge about the usefulness and ecology of snakes (PANDEY et al., 2016). Consequently, the negative image contributes to a sense of repulse and will to kill snakes, regardless of being venomous or not (KNIGHT, 2008; PROKOP; TUNNICLIFFE, 2008; MOURA et al., 2010; ALVES et al., 2014).

Human-snake relations become controversial when fear and aversion overcome the ecological importance and utility of these animals. The negative perception of snakes is very common worldwide, including Brazil, directly compromising snake conservation efforts (SEIGEL; MULLIN, 2009; MOURA et al., 2010; MENDONÇA et al., 2014). Brazil has a wide diversity of snakes, with about 405 described species (COSTA; BERNILS, 2018), distributed along different biomes and ecosystems, among which is the Caatinga biome, endemic to the country (RODRIGUES, 2003; FREIRE et al., 2009). Caatinga holds high levels of biodiversity and endemisms (TABARELLI et al., 2013; GUEDES et al., 2014; SILVA et al., 2017).

In the state of Rio Grande do Norte (RN), located in the Northeast Brazil, 80\% of its municipalities are located in the semiarid region with predominance of Caatinga (SUDENE, 2017). Of the 112 snake species described for the entire Brazilian Caatinga (GUEDES et al., 2014), about 70 species inhabit the RN Caatinga (COSTA and BERNILS, 2018), including the three most common venomous species: the Caatinga lancehead, Bothrops erythromelas; the Caatinga true coral snake, Micrurus ibiboboca; and the tropical rattlesnake, Crotalus durissus (Table 1).

Among the venomous species found in the RN state, snakes of the genus Bothrops stand out as the most renowned and those with higher epidemiological risk of snake bites. In Santa Cruz, a municipality located in the micro region of Borborema Potiguar, identified as the region of higher incidence of snake bites in the whole state (DA COSTA et al., 2019; data available at the Notifiable Diseases Information System - SINAN), the local population can recognize the morphology of snakes and indicate their habits and probable sites of occurrence (DA COSTA et al., submitted). However, even though these populations are strongly integrated with the surrounding wildlife (ALVES et al., 2010; ALVES et al. 2012; ALMEIDA and SANTOS, 2017), snake bites are frequent. Consequently, the first reaction of a human when encountering a snake is to attempt to kill it, a behaviour that is common in Brazil (MOURA et al., 2010; PIRES et al., 2018) 
and elsewhere (e.g. PANDEY et al., 2016).

In the semiarid regions of Northeast Brazil, many schools are in areas with high rates of snakebite accidents, and where myths and negative perceptions of snakes persist (e.g. ALVES et al., 2012; DA COSTA et al., submitted). Thus, investing in educational activities that aim at promoting environmental knowledge and a positive attitude for local species is a mean to favour building an adequate relation between humans and other animals, as snakes. This, in turn, can indirectly minimize the number of killed snakes and of snake bites (SOARES et al., 2014; PANDEY et al., 2016; PONTES et al., 2017).

Schools are recognized as the prime environment to promote links between popular and scientific knowledge, allowing to bridge students' daily life to the didactic contents (SILVA, 2012; PONTES et al., 2017). Teachers, being the main responsible of the learning process within schools, should adopt new methodologies that favour students' participation and interaction. But at least in Brazil, most times they can only count with didactic books which have many conceptual errors about snakes or do not prioritize snake bite problematics (SILVA et al., 2011). Such conceptual errors, the inclusion of images that do not match Brazilian snakes and inadequate first aid guidelines are some of the problems that can be found in textbooks (SANDRIN et al., 2006).

In this context, schools can contribute to overcome the problem involving students, teachers and other representatives of the community, since the first school years, using context-based educational strategies and tools, considering the school region, and integrating local and scientific knowledge. Such initiatives have the potential to raise awareness of the importance of local species to the conservation of the ecosystem, and to reduce human prejudice towards snakes and other stigmatized animals (MOURA et al., 2010; GOMES et al., 2017) and snake bites (PANDEY et al., 2016; MENDES, 2018). Based in this premise, the central research question is: can a scientific and environmental education content created using didactic strategies that value the previous knowledge of the local communities and context-based information help to overcome negative beliefs about snakes and thus lead to less frequent and less severe snake bite accidents and species preservation?

Aiming at overcoming these problems, this work sought to produce a novel and accurate core content that, using distinct and interdisciplinary languages, and bridging scientific and local knowledge, could communicate different aspects about snakes from Caatinga and information related with snake bites. That core content was then adapted to three innovative and context-based materials - a manual, a book and an exhibition.

The educational resources produced will allow easy access and sharing of factual information about snakes, further contributing to science education at formal and informal teaching and learning settings.

\section{Methodology}

This study builds on previous work by the authors on the epidemiology of snake bites in Northeast Brazil (DA COSTA et al., 2019) and the ethnozoology of such bites 
from the victims' point of views (DA COSTA et al., submitted). Other works that used didactic and science communication materials produced from the environmental perception, local ecological knowledge and science engagement in the semiarid regions of Northeast Brazil and that corroborates the relevance of these educational strategies (SILVA; FREIRE, 2010; OLIVEIRA et al., 2017) also supported the development of the environmental education resources of this research.

The resources and their evaluation strategies were developed by the authors in the scope of this study. The evaluation was performed with the collaboration of teachers and students from public schools from the Santa Cruz municipality, located on RN state, microregion of Borborema Potiguar, semiarid and within Caatinga domain (VELLOSO et al., 2002). This region was selected because it has the highest incidence of snake bites on the state (DA COSTA, et al., 2019). The materials were developed to deliver current, relevant and contextualized information about the snakes from the region and actions to prevent snake bites or minimize their health consequences. Thus, it contributes to the teaching and learning of this theme and to public health.

The Secretary of Education of Santa Cruz municipality helped selecting schools and target-groups: one secondary school in an urban area and one basic school in a rural zone. The basic school is located in Bom Sucesso community (620'38.4"S 35 $\left.56^{\prime} 55.0^{\prime \prime} \mathrm{W}\right)$, the most populated community of the municipality and with the highest frequency of snake bites (DA COSTA, et al., 2019).

\section{"Educational resources"}

The development of the resources started by defining a single core content that was later strategically adapted to different publics, matching the language and images to the target-groups profiles. As such, three educational resources were developed: 1) a teacher's manual, 2) an educational support (paradidactic) book and 3) a travelling exhibition.

The core content includes key concepts related to snake bites and its epidemiology, with information about i) general characteristics of the common snakes from Northeast Brazil (Table 1), ii) prevention measures and actions in case of snake bites, and iii) the relevance of snakes for ecology, pharmacology, economy and culture. It integrates scientific and local knowledge, following previous interviews with Santa Cruz residents (DA COSTA et al., submitted), and several photos of local snake species. While the manual targets teachers from the basic public-school network and presents all the information with a technical approach, the exhibition and the book target basic and secondary school students, respectively, and contain the same information conveyed in the manual but in a more accessible and less technical language. The book has 16 additional pages with games and activities, included as a ludic way to help in knowledge construction, engaging students and facilitating the understanding of the scientific content. 
Table 1 - Snakes from the semiarid region of the state of Rio Grande do Norte, Northeast Brazil, that are more easily seen by the population (KOLODIUK et al., 2016 and DA COSTA, et al., submitted). Venomous species are indicated with the symbol $\Delta$ before the popular name.

\begin{tabular}{ll}
\hline \multicolumn{1}{c}{ Popular name } & \multicolumn{1}{c}{ Scientific name } \\
\hline$\Delta$ Caatinga lancehead & Bothrops erythromelas Amaral, 1923 \\
$\Delta$ Caatinga true coral snake & Micrurus ibiboboca (Merrem, 1820) \\
$\Delta$ Tropical rattlesnake & Crotalus durissus Linnaeus, 1758 \\
Common boa & Boa constrictor Linnaeus, 1758 \\
Rainbow boa & Epicrates assisi Machado, 1945 \\
Green snake* & Philodryas nattereri Steindachner, 1870 \\
Brown vine snake & Oxybelis aeneus (Wagler,1824) \\
Brazilian false coral snake & Oxyrhopus trigeminus (Duméril; Bibron; Duméril, 1854) \\
$* *$ & Thamnodynastes phoenix Franco; Trevine; Montingelli; \\
Black false boa & Zaher, 2017 \\
Lichtenstein green racer & Pseudoboa nigra (Duméril; Bibron; Duméril, 1854) \\
* Common name given to all species from the genus Philodryas. \\
** The species was only described in 2017 and no English common name is known. \\
Source: this work, based on KOLODIUK et al. (2016) and DA COSTA et al. (submitted).
\end{tabular}

The three resources are available as printed or digital materials. The latter can be downloaded from the website of the Herpetological Laboratory of the Federal University of Rio Grande do Norte (http://abherpeto.cb.ufrn.br/popc.html).

\section{"Evaluation of the educational resources"}

To evaluate the educational and attitudinal potential of the produced core content, a methodological framework was designed to each pair 'resource + target-group': teachers and manual, secondary school students and book, and basic school students and exhibition.

\section{"Evaluation of the manual"}

To evaluate the manual, two questionnaires were developed, to be used before and after the reading. The pre-questionnaire allows assessing teachers' previous knowledge about the information on the material and has seven open questions related to the identification of venomous and non-venomous Caatinga snakes, the ecologic importance of snakes, other uses for snakes, and what to do to avoid snake bites, in case of encountering a snake and in case of accident. The post-questionnaire allows assessing acquired knowledge after reading the manual, and has three additional questions to assess the teachers' 
general opinion about the material and its utility in the classroom. The questionnaires were validated through a pre-test with seven teachers that were not part of the targetgroup. This step allowed identifying some problems with the initial formulation of the questions and to adjust language to facilitate participants' understanding.

Two days were scheduled to visit the school and all teachers were previously invited to be present and participate in this research. On the first day, teachers were asked to complete the pre-questionnaires and were offered a copy of the manual. On the second visit, seven days after, the teachers were invited to complete the post-questionnaire.

The teachers' answers were grouped in two dimensions: knowledge (about the content) and appreciation (of the material). For the knowledge dimension, the answers to the pre- and post-questionnaires were analysed, whereas for the appreciation dimension only the three additional questions on the post-questionnaire were considered. A qualitative analysis was performed for each category of question about knowledge, to identify the most adequate answers in terms of vocabulary and mobilized scientific knowledge. To evaluate the appreciation of the manual, answers towards its content and the will to use it in class were considered.

\section{"Evaluation of the book"}

Personal Meaning Maps (PMM; FALK et al., 1998) were used to evaluate the book. This method can inform gains in knowledge in diverse educational environments (e.g. FALK et al., 1998; BOWKER; JASPER, 2007; CAMPOS, submitted). The methodology is based on the principle that each individual learns according to its personal context, the social context of learning and to the physical context where the learning takes place, allowing to compare concepts and meanings before and after an educational experience. In this work, this methodology was also used to assess changes in students' attitudes and perceptions toward snakes.

Again, two days were scheduled to visit the selected secondary school. Before being offered the books, each student received a sheet of paper with the word 'snake' and was asked to use the remaining space of the sheet to write words, phrases and/or to draw everything that comes to their mind related to snakes. Next, each student returned the maps and received a copy of the book, to read the texts and complete the games. Two days after, on the second visit, the students received their maps and were invited to expand on previous meanings using a pen of a different colour (to distinguish meanings and thoughts before and after the book). The students also returned the books that were photographed and later analysed regarding the quantity and quality of the completed games, allowing evaluating students' acceptance of the material. Afterwards, all books were given back to the students so that they could keep the information.

To analyse the Personal Meaning Maps, words, phrases and drawings were first counted and classified as 'positive perception', 'negative perception' or 'neutral perception'. Categories were identified from common themes, wrote or drawn on the PMM. Words, phrases and drawings were then classified in the different categories, allowing quantifying changes in knowledge about snakes and prevention and actions related to 
snake bites, in the dimensions of 'extent', 'breadth' and 'depth' (as described in FALK et al., 1998; CAMPOS, submitted).

The dimension 'extent' was obtained by counting the number of words, phrases and drawings in each PMM, before and after reading the book. 'Breadth' measured changes in the number of categories expressed in the PMM before and after reading, in the form of words, phrases and drawings. 'Depth' expressed changes in understanding levels, measured by a 3-points quantitative scale that evaluated the degree of elaboration and use of relevant information in the different categories (adapted from BOWKER; JASPER, 2007).

The analysis was done independently by two of the authors (MKBC; RC) and subsequently compared. Discrepancies were discussed and resolved. The comparison between words and phrases classified as positive and negative perception before and after reading the book allowed evaluating changes in the perception of snakes.

Finally, the acceptance of the book was quantified through the number of games and activities completed by the students.

\section{"Evaluation of the exhibition"}

To evaluate the exhibition, an interactive activity called 'Myth or Truth' was designed. The activity consisted of a list of 10 phrases about snakes, prevention of snake bites and attitudes in case of accident, five myths and five truths. The myths were selected from the interviews with Santa Cruz locals (DA COSTA et al., submitted). The phrases were laid on a table with a small safe box next to it. Before visiting the exhibition, each student received 20 cards, 10 orange (representing myths) and 10 green (representing truths) and were asked to read the 10 phrases and classify them accordingly: for example, if the phrase was considered true, the student should put a green card on the safe box next to that phrase. After visiting the exhibition, the students repeated the classification. This evaluation was done on a single-day visit to the selected basic school.

The number of green and orange cards in each safe box before and after visiting the exhibition was counted. The students' classifications were considered correct if a myth was identified as a myth (i.e. with an orange card) and truth as truth (i.e. with a green card). Using Wilcoxon (W) and chi-square $\left(\chi^{2}\right)$ tests, correct classifications before and after the exhibition were compared to evaluate significant changes in students' knowledge, perceptions and attitudes.

SPSS Statistics 20 software package was used in all quantitative analyses.

\section{Results}

"Manual"

Seven teachers answered the pre-questionnaire, four females $(57 \%)$ and three males (43\%), aged between 25 and 44 years old (average 32 years; $S D=6.37$ ); of these, only three answered the post-questionnaire. All teachers have higher education in diverse areas (mathematics, Portuguese, Spanish, arts, tourism, chemistry, physics, history and 
geography). All live in Santa Cruz municipality except one, who lives in a neighbour municipality, Tangará, also located within the microregion of Borborema Potiguar.

The first question asked to cite popular names of common snakes from the region, classifying them as venomous and non-venomous. Thirteen names were cited of which $11(85 \%)$ were in fact common snakes from the region: Caatinga lancehead, Caatinga true coral snake and tropical rattlesnake as venomous snakes, and brown vine snake, green snake, common boa, rainbow boa, water snake, black false boa, Lichtenstein's green racer and Brazilian false coral snake as non-venomous snakes. Two other animals were misclassified as being from Caatinga region: Southern American bushmaster (Lachesis muta; Linnaeus, 1766) from the Atlantic Forest and Amazonia biomes, and Amphisbaenia (amphisbaenians or worm lizards in English but known as two-head snake in Brazil), a reptile that is not a snake.

All teachers correctly identified the Caatinga lancehead as a venomous snake from the region, six (86\%) also identified the tropical rattlesnake and four (57\%) the three most common venomous snakes from Caatinga: the Caatinga lancehead, the tropical rattlesnake and the Caatinga true coral snake. All teachers that completed the post-questionnaire identified the Caatinga lancehead and the tropical rattlesnake, and one also identified the Caatinga true coral snake. Of the 10 common Caatinga snake listed on the postquestionnaire, only one was misidentified: caninana, a non-venomous snake from forested areas. Teachers recognized the importance and utility of snakes in different processes and sectors: medicine, economy and environmental equilibrium.

In relation to snake bites, the number of correct attitudes to avoid bites increased from eight to 10 after reading the manual (Figure 1); the number of incorrect actions after a snake accident decreased from one ('do a tourniquet') in the pre-questionnaire to none in the post-questionnaire. As for what to do when encountering a snake, all teachers stated that they would try to keep a safety distance and report to competent authorities, both before and after reading the manual. If the encounter resulted in a snake bite, then the teachers would prioritize looking for treatment, not killing the snake. Three (43\%) of the teachers that gave this answer justified their actions referring the ecological and medical importance of snakes. Two teachers further mentioned the need to identify the snake. All teachers that completed the post-questionnaire declared their intention of using the manual in the classroom. 
Figure 1: Distribution of the percentage of mentions to measures to prevent snake bites by the teachers in the pre and post-questionnaires, applied in public schools from the Santa Cruz municipality, Rio Grande do Norte.

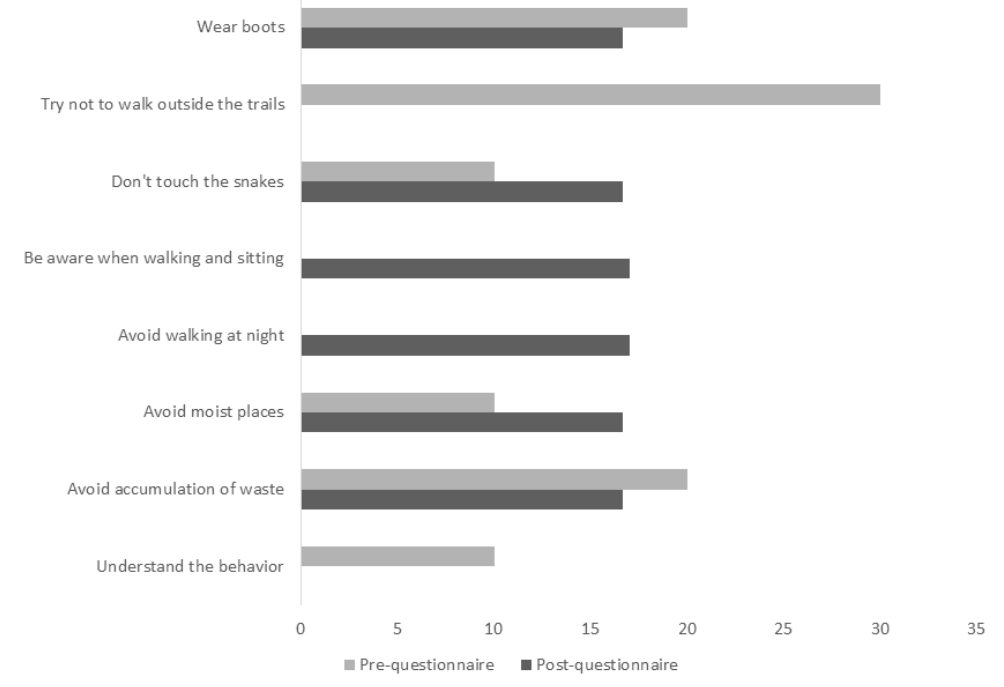

Source: this work.

"Book"

Thirty-six secondary school students, 14 (38.8\%) females and 22 (61.1\%) males, aged between 16 and 18 years old (mean=17), completed the first PMM; of these, 18 (50\%) were present in the second day of the evaluation, complementing their PMM (Figure 2). Only fully completed PMM, before and after reading the book, were analysed $(\mathrm{N}=18)$. 
Figure 2: Example of a personal meaning map before (in black) and after (in blue) reading the book by secondary school students from the Santa Cruz municipality, Rio Grande do Norte

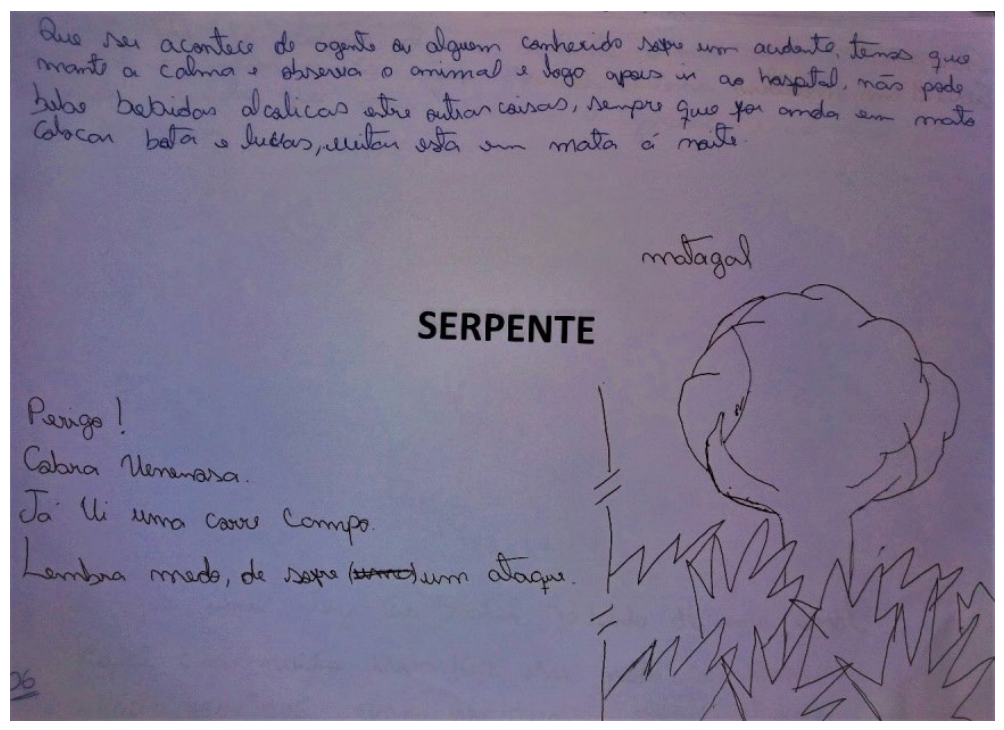

Source: this work.

In total, the first PMM had 100 expressions, including words, phrases and drawings, and the second PMM contained 154, representing a significant gain in knowledge about snakes $(54 \% ; \mathrm{W}=-3.750 ; \mathrm{p}<0.001)$. In relation to the type of perception (negative, positive or neutral) towards snakes, after reading, the expressions classified as negativeperception significantly decreased, while expressions classified as positive-perception significantly increased $(\mathrm{W}=-3.422 ; \mathrm{p}=0.001, \mathrm{~W}=-2.177 ; \mathrm{p}=0.029$; respectively); the variation in the expressions classified as neutral perception was not significant (W=1.394; $\mathrm{p}=0.163$ ).

Eleven categories of knowledge were identified in the PMM (Table 2). Changes in the number of categories identified between the first and the second PMM underline gains in knowledge and understanding of the book content. As such, the analysis of the PMM allowed identifying variation between one and five categories before reading the book and two and six after reading, with a maximum of three categories before and after reading. This result indicates a significant increase in knowledge and understanding in the dimension breadth $(T=-5.359 ; \mathrm{p}<0.001)$. The categories 'actions after snake bite' and 'prevention' only appear in the second PMM, demonstrating a higher complexity in mobilizing knowledge gained after reading the book. 
Table 2 - Description of the categories identified in the Personal Meaning Maps (PMM), applied with students from public schools from the Santa Cruz municipality, Rio Grande do Norte. In bold are the categories identified only in the second PMM.

\begin{tabular}{|c|c|}
\hline Category & Description \\
\hline Biology & Characteristics of snakes \\
\hline Ecology & $\begin{array}{l}\text { Relations between snakes and other species and with the } \\
\text { environment }\end{array}$ \\
\hline Encounters & $\begin{array}{l}\text { Personal experiences or stories related to acquaintances } \\
\text { about encounters with snakes }\end{array}$ \\
\hline Sensations & Feelings toward snakes \\
\hline Uses & Diverse uses of snakes \\
\hline Identification & List of snake species \\
\hline True stories & $\begin{array}{l}\text { Personal experiences or stories related to acquaintances } \\
\text { about snakes }\end{array}$ \\
\hline Popular stories & Myths or others beliefs about snakes \\
\hline Snake bites & Stories of snake bites \\
\hline Actions after snake bites & Actions in case of snake bites \\
\hline Prevention & Actions to prevent snake bites \\
\hline
\end{tabular}

Source: this work.

Changes in understanding were evaluated by scoring the correct use of relevant information and the complexity of the phrases and/or the drawings. An increase of 112 points (44\%) between the first and the second PMM was observed, which was interpreted as a significant increase in the quality and depth of knowledge and understanding (W=3.734; $\mathrm{p}<0.001)$.

The 18 students that were present in the second visit loaned the books for an overview of the completed games. A mean of 12 games were completed $(\mathrm{min}=3$; $\max =16)$; the pages with drawings to colour were the ones mostly left undone.

\section{"Exhibition"}

The exhibition was evaluated based on classifications obtained from 28 basic school students, 11 (39\%) males and 17 (61\%) females, with a mean age of 11 years old. Overall, there was an increase in the mean of the correct classification of the 'myth' and 'truth' phrases after visiting the exhibition (17.3 before and 19.5 after; $W=1.608$; $\mathrm{p}=0.108$ ). This change was more noticeable when the phrase was a 'myth' (Table 3 ).

Table 3 - Classification on the 'Myth and Truth' activity before and after visiting the exhibition Students from public schools from the Santa Cruz municipality, and results from the significance analysis of changes observed in the number of correct classifications. $\mathrm{M}=\mathrm{myth} ; \mathrm{T}=$ truth . 


\begin{tabular}{lllll}
\hline \multirow{2}{*}{ Phrases } & Before & After & & \\
\cline { 2 - 2 } & & $\chi^{2}$ & p-value df \\
\cline { 2 - 3 } & Nr of correct classification $(\%)$ & & \\
\hline
\end{tabular}

(M1) Drinking water is not allowed in case of snake bite.

$12(43 \%)$

(M2) Using creams for burns in the snake bite site alleviates the pain.

(M3) In case of snake bite, if you drink milk from Jatropha mollissi$m a^{1}$ there's no need to go to the hospital.

(M4) In case of snake bite, washing the site with smoke water ${ }^{1}$ neutralizes the effect of the venom.

(M5) Perforating the snake bite site helps the venom leave the body.

(V1) Doing physical exercise after the snake bite speeds up the effect of the venom.

(V2) The antiofidic serum (snake antivenom) is made from the snake venom itself.

(V3) The Caatinga lancehead is the snake responsible for most snake bites.

(V4) Do not tie (do a tourniquet) the injured limb.

(V5) In case of snake bite urgently look for a hospital.

$9(32 \%)$

$14(50 \%)$

$13(46 \%)$

$11(39 \%)$

$24(86 \%)$

$21(75 \%)$

$28(100 \%)$

$13(46 \%)$
$19(68 \%)$

$16(57 \%)$

15 (54\%)

$\begin{array}{lll}9.947 & 0.002 \quad 1\end{array}$

$16(57 \%)$

$18.200<0.001 \quad 1$

$16(57 \%)$

$13.588<0.001 \quad 1$

$23(82 \%)$

$21.467<0.001 \quad 1$

$26(93 \%)$

$6.462 \quad 0.011$

1

27 (96\%)

$9(32 \%)$

$15.304<0.001 \quad 1$

* No statistic value to the data because the values are equal.

${ }^{1}$ Milk from Jatropha mollissima, leite de pinhão in Portuguese, and smoke water, água de fumo in Portuguese, are traditional remedies popular in Northeast Brazil as home treatments for snake bites (DA COSTA et al., submitted).

Source: this work. 


\section{Discussion}

The evaluation of the three innovative educational resources - a manual, a book and an exhibition - made by teachers and students from basic and secondary schools allowed verifying their utility in overcoming negative beliefs about snakes. Despite the low number of teachers that completed the post-questionnaire, the ones that answered gave very positive feedback on the manual and stated their intention of using it in class. Together, results show the potential of the material for education and to change perceptions of snakes as described below.

\section{"Knowledges and attitudes towards snakes"}

Overall, both teachers and students showed reasonable prior knowledge about the snakes that inhabit the Northeast Brazilian Caatinga. However, some teachers misidentified species from other biomes (such as Southern American bushmaster and caninana, common in the Atlantic Forest) and mentioned a species that is not a snake (Amphisbaenia). The latter is a relatively common mistake, as these animals have a long and feetless body, very similar to snakes (LIMA et al., 2010; FERNANDES-FERREIRA et al., 2011). After having access to the content developed in this work, previous knowledge of teachers and students was complemented and changed in a positive manner. For example, after reading the content, all teachers correctly indicated the only three venomous species from the region: the tropical rattlesnake, the Caatinga true coral snake and the Caatinga lancehead. The Caatinga lancehead was also the most frequently mentioned species by students, being recognized as venomous and identified as the one that causes most snake bites ('The snake that attacks the most is the Caatinga lancehead and the one that most frequently bites humans.'). The morphological recognition of the Caatinga lancehead is probably connected to the abundance of these snakes and the high incidence of snake bites involving the species, as described by Foesten et al. (2016). In a study about superstitions associated to snakes from the Brazilian Northeast, the Caatinga lancehead was also recognized as venomous and potentially deadly (FERNANDES-FERREIRA et al., 2011).

Being able to correctly identify a snake is not only important for proper treatment in case of snake bite, but also to avoid negative reactions towards all snakes, which may lead to killing harmless species. For example, the rainbow boa (Epicrates assisi), a completely inoffensive species when talking about venom, has always been assumed as being venomous due to its triangular head (VANZOLINI et al., 1980), feature that other than venomous species have. In the scope of this work, the species Thamnodynastes phoenix never caused any fatal accident like the Caatinga lancehead, even though it has posterior teeth with the ability to leek toxic substances; also, the species belong to a different family that is considered to be non-venomous (DA COSTA et al., 2019).

When asked about what to do in case of encountering a snake, all teachers declared that they would call authorities and keep a safety distance from the animal. They further stated that even in the case of a snake bite they would not kill the snake because of its ecological importance. Among students, a similar result was obtained but only after reading the book ('Snakes are also important to the ecosystem, because they are predators of 
animals that disseminate diseases like mice'). These facts show that environmental education and perception are ways to construct knowledge, as learning and understanding local environments promotes the will to take care and protect them (CAMPOS et al., 2011). Furthermore, our results clearly show that before reading the content students expressed negative feelings towards snakes, directly associating snakes to danger. This association most likely leads humans to be hostile to snakes, killing them for no reason (SOARES et al., 2014). However, the same students changed their perception and attitude after reading the book, with a significant increase in positive expressions towards snakes. Albeit finding resistance to change negative or prejudicial attitudes anchored in beliefs or cultural aspects can be common (SANTOS; LIRA-DA-SILVA, 2012; PONTES et al., 2017; MENDES, 2018), the content lead to positive changes in knowledge about the importance of snakes to the environment and to human societies among the students who had access to the materials. Thus, the content developed in this study has the potential to positively change perceptions of snakes, promoting the recognition of their ecologi$\mathrm{cal}$, biomedical and economic importance. In turn, changes in perception may lead to more positive attitudes towards these animals, supporting snake conservation measures. Regular monitoring of snakes abundance and conservation in areas where the materials produced in the scope of this work are included in environmental education actions will allow assessing their effective contribution to attitudinal changes towards snakes.

\section{"Measures to prevent snake bites"}

Globally, snake bites are a threat to both public health and snake conservation (e.g. PANDEY et al., 2016). Given the high number of snake bites in this region of the Northeast Caatinga highly associated with the predominance of agriculture activity (DA COSTA et al., 2019), it is important to increase the knowledge of local populations on prevention measures, minimizing encounters with snakes and thus reducing the number of bites. Teachers showed high knowledge on how to prevent snake bites, indicating actions like 'always follow designated trails', 'observe where to step or seat, especially at night', or 'wear boots and avoid accumulation of wastes' (Figure 1). Some teachers also stated their understanding about snake behaviour, referring the importance of not disturbing these animals. The use of protection equipment like gloves and boots, especially by those who live or work in areas with increased risk of snake bites, may help avoiding most bites. Wearing boots, for example, could have prevented about $85 \%$ of snake bites reported in Amazonian river communities (WALDEZ; VOGT, 2009). Results from this study were similar to those obtained in another study, where participants also cited wearing boots, keep the space near the houses clean and avoid approaching a snake as main prevention action (SANTOS; LIRA-DA-SILVA, 2012).

Again, among students, only after reading the content was possible to detect recognition of the importance of measures to prevent snake bites. This led to the identification of a new category, named 'prevention', present only on the post-reading PMMs (Table 2). The expressions classified in this category included the use of boots and gloves and avoiding walking in the bush at night ('Avoid being in the bush at night'; 'whenever 
you walk in the bush wear boots and gloves'). Thus, the content contributed not only to increase knowledge and change perceptions but also helped students to critically reflect about their behaviour in regions where venomous snakes occur. Hence, the generalize use of the materials produced in this study may contribute to the reduction of snake bite accidents in this region. As referred above, also in relation to this aspect will be necessary to regularly monitor the number of accidents and compare its evolution with the use of these materials to assess their effectiveness in diminishing snake bites.

\section{"Actions in case of snake bites"}

The most cited actions in case of a snake bite were 'looking immediately for a hospital' and 'identifying the snake'. However, as before, students only expressed these actions after reading the book. This prompted the identification of a new category, called 'actions after snake bites', present only on the post-reading PMMs (Table 2). The content helped students to state the adequate actions in case of snake bite, such as keeping calm, do not ingest alcoholic drinks and search for urgent medical aid ("Maintain the calm and describe the animal and right after go to the hospital, you can't drink alcoholic drinks among other things'; 'I understood that if an accident happens the most ideal is to go to a hospital and drink plenty of water, so we should be very carefully'). These procedures are positive because the time between an accident and the beginning of the treatment is very important to the prognosis (MISE et al., 2018). Also, the visual identification of the snake facilitates the diagnostic, as it helps selecting appropriate serologic treatment. Albeit species identification depends of a number of characteristics, some are more distinctive. For example, features found in venomous snakes that inhabit the semiarid region of Rio Grande do Norte, as the presence of the loreal pit (lancehead), presence of rattles (rattlesnake), colorful rings around the body (coral), may be easily recognized by local populations if they have access to materials like the ones here analyzed, produced to contain information about the species that were most often identified as being involved in snake bite accidents in the region (DA COSTA et al., 2019). Recognizing these features may help the doctors to act faster in a first phase of the treatment. This result further supported the importance of promoting local knowledge about snakes in a public health context (PINHO; PEREIRA, 2001), and of elaborating didactic and informative materials based on species that inhabit the regions to a greater dissemination of such knowledge.

Several myths related to first aid procedures were identified among students, such as benefits of puncturing the biting spot (a procedure that many believe helps taking the venom out of the wound), a very old treatment practice, considered an erroneous attempt to extract the venom (FRY, 2018). After reading the content, students were able to correctly identified the adequate actions (Table 3), suggesting that the educational resource has the potential to contribute to minimize the negative impact of snake bites in health.

The games and activities available in the book were attractive to the students, who completed about $75 \%$ of them. The activities that needed an extra resource, such as colouring pencils, were the ones left unfinished. Still, some students used their ballpoint pen to colour the Caatinga true coral snake in one of the activities. Playful activities and 
alternative methodologies are tools that contribute to learning and understanding new knowledge. When teaching about snakes, this type of resources should be privileged, making the subject attractive to the students (CARVALHO; BRAGA, 2013; BERNARDES et al., 2016).

\section{Conclusions}

Topics approached in the classroom should go beyond the physical frontiers of the school and find applications in the students' daily life (UHMANN; ZANNON, 2013). The construction of knowledge starts on the dialogue between local cultural and social aspects and the scientific knowledge, which also applies when talking about snakes (BERNARDES et al., 2016). Due to the inclusion of real Caatinga snakes and the relevance of the information about snakes and snake bites, the environmental education resources developed in this study are interdisciplinary materials that should not be restricted to schools.

Taken together, the results from the evaluation of the three educational resources empirically shows that this content is valid for science education and for communities because they favour the identification of the snakes that are most often found by local populations, in the region of this work (KOLODIUK et al., 2016; DA COSTA, et al., submitted), from the identification of some morphologic characteristics and habits, helping minimizing snake bites and generating positive perception, thus potentially contributing to snake conservation.

Albeit focusing on snakes, changes in the perception towards these animals here documented may generate a positive impact on the environmental perception of the populations towards local environment, an important indicator to the preservation of species and of the ecosystems (e.g. SILVA; FREIRE, 2010; LUCENA; FREIRE, 2014). Hence, a wide dissemination of materials able to promote change in the perception towards snakes in local communities, as the ones here described, may promote an environmental culture supporting snake protection, as defended by other authors (e.g. ALVES et al., 2010; ALVES et al., 2012). We highlight the importance of adapting this type of materials to local species and knowledges, not neglecting the dialogue with scientific knowledge about snakes and the national curricular framework.

\section{Acknowledgements}

The work was supported by the Coordenação de Aperfeiçoamento de Pessoal de Nível Superior - CAPES, Brazil, under Finance Code 001; and CES-UC and Fundação para a Ciência e a Tecnologia (FCT), Portugal, under Strategic Programs UID/SOC/50012/2013 and UIDP/50012/2020. RC is supported by FCT (POCH and European Social Fund, Contract-Program DL57/2016/CP1341/CT0001). EMXF is supported by Conselho Nacional de Desenvolvimento Científico e Tecnológico CNPq, Brazil - Process 437719/2018-9, and MKBC by CAPES, Brazil. We thank JMF for the English revision. 


\section{References}

ALMEIDA, M. L. A; SANTOS, C. A. B. Panorama da relação Humana com a Fauna Silvestre no Semiárido Brasileiro. Revista Científica da FASETE, v.3, n. 1, p. 187-201, 2017.

ALVES, R. R. N., et al. Bird-keeping in the Caatinga, NE Brazil. Human Ecology, v.38, n. 1, p. 147-156, 2010. doi.org/10.1007/s10745-009-9295.-5.

ALVES, R. R. N., et al. A zoological catalogue of hunted reptiles in the semiarid region of Brazil. Journal of Ethnobiology and Ethnomedicine, v. 8, n. 27, 2012. doi.org/10.1186/1746-4269-827.

ALVES, R. R. N., et al. Students' atitudes toward and knowledge about snakes in the semiarid region of Northeastern Brazil. J Ethnobiology Ethnomedicine, v.10, n.30, 2014. doi. org/10.1186/1746-4269-10-30.

BERNARDES, L. S., et al. Uso de Metodologias Alternativas no Ensino de Ciências: Um Estudo Realizado com o Conteúdo de Serpentes. Ensino, Saúde e Ambiente, v.9, n.1, p. 63-76. 2016.

BOWKER, R.; JASPER, A. 'Don't forget your leech socks'! Children's learning during an Eden education Officer's workshop. Research in Science \& Technological Education, v. 25, n. 1, p. 135-150, 2007. doi.org/10.1080/02635140601053732.

CAMPOS, S. R. M.; NEHME, V. G. F.; COLESANTI, M. T. M. A Cidade Sustentável e o Desafio da Educação Ambiental na Superação da Utopia. Revista Geográfica de América Central, v.2, n.47E, 2011. https://www.revistas.una.ac.cr/index.php/geografica/article/view/3008

CAMPOS, R. Alternative methods for evaluation and diagnostic in different teaching/learning contexts: the use of Personal Meaning Maps. Submetido.

CARVALHO, E.F.F; BRAGA, P. E. T. O Jogo de Tabuleiro como uma Estratégia Auxiliadora para o Ensino de Zoologia, com Ênfase para as Serpentes. Ensino, Saúde e Ambiente, v. 6, n. 3, p. 202-217, 2013. doi.org/10.22409/resa2013.v6i3.a21152.

COSTA, H. C.; BÉRNILS, R. S. (Org.). Répteis brasileiros: Lista de Espécies 2018. Herpetologia Brasileira, v. 8, n. 1, p. 1-64, 2018. http://sbherpetologia.org.br/wp-content/uploads/2016/10/ lista-de-repteis-2018-2.pdf

COSTA-NETO, E. M. Conhecimento e Usos Tradicionais de Recursos Faunísticos por uma Comunidade Afro-brasileira. Resultados Preliminares. Interciência, v. 25, n. 9, p. 423-431, 2000. https:/www.redalyc.org/comocitar.oa?id=33905105

DA COSTA, M. K. B.; et al. Snakebite Accidents in Rio Grande do Norte State, Brazil: Epidemiology, health management and influence of the environmental scenario. Tropical Medicine and International Health, v. 24, n. 4, p. 432-441. 2019. doi:10.1111/tmi.13207.

DA COSTA, M. K. B., et al. Perceptions and attitudes of snakebite victims in a risk area in Northeast Brazil. Submetido. 
FALK, J. H.; MOUSSOURI, T.; COULSON, D. The Effect of Visitors' Agendas on Museum Learning. Curator, v. 41, n. 2, p.107-120, 1998. doi.org/10.1111/j.2151-6952.1998.tb00822.x.

FERNANDES-FERREIRA, H.; et al. Folklore concerning snakes in the Ceará State, northeastern Brazil. Sitientibus séria Ciências Biológicas, v. 11, n. 2, p. 153-163, 2011. doi.org/10.13102/ $\operatorname{scb} 70$.

FOESTEN, M. H.; TOZETTI, A. M.; HENKES, J. A. Avaliação do nível de conhecimento da ofidiofauna por moradores rurais do Vale do Rio dos Sinos, Sul do Brasil. Revista Gestão $\mathbb{\&}$ Sustentabilidade Ambiental, v. 5, n. 2, p. 175-199, 2016. http://dx.doi.org/10.19177/rgsa. v5e22016175-199

FREIRE, E. M. X.; et al. Répteis Squamata das Caatingas do Seridó do Rio Grande do Norte e do cariri da Paraíba: síntese do conhecimento atual e perspectivas. In Recursos Naturais das Caatingas: uma visão multidisciplinar, edited by E. M. X. Freire, p. 51-84. Editora da UFRN: Brazil, 2009.

FRY, B.G. Snakebite: When the Human Touch Becomes a Bad Touch. Toxins, v.10, n. 170, p. 1-24. 2018. doi.org/10.3390/toxins 10040170

GOMES, M. C. B., COSTA-NETO, E. M.; ALVAREZ, M. R. V. Ethnozoology of bats (Mammalia, Chiroptera) in Feira de Santana Municipality, Bahia State, North-eastern Brazil. Brazilian Journal of Biological Sciences, v. 4, n. 7, p.147-156, 2017. doi.org/10.21472/bjbs.040715.

GUEDES, T. B., NOGUEIRA, C.; MARQUES, O. A. V. Diversity, natural history, and geographic distribution of snakes in the Caatinga, North-eastern Brazil. Zootaxa, v. 3863, n. 1, p. 001 093. 2014. doi.org/10.11646/zootaxa.3863.1.1.

HESS, P.L.; SQUAIELLA-BAPTISTÃO, C. C. Toxinas Animais: Serpentes da Família Colubridae e seus Venenos. Estudos de Biologia, Ambiente e Diversidade, n.34, v.83, p.135-142. 2012. doi.org/10.7213/estud.biol.7326.

KNIGHT, A. J. 'Bats, Snakes and Spiders, Oh my!': How Aesthetic and Negativistic Attitudes, and Other Concepts Predict Support for Species Protection. Journal of Environmental Psychology, v.28, n. 1, p. 94-103, 2008. doi.org/10.1016/j.jenvp. 2007.10.001.

KOLODIUK, M. F; ANDRADE, M. J. M.; JORGE, J. S.; RIBEIRO, M. M.; SALES, R. F. D.; RÊGO, B. P.; FREIRE, E. M. X. Os calangos e as cobras da Serra e do Sertão. Cartilha educativa, laboratório de Herpetologia da Universidade Federal do Rio Grande do Norte, 2016.

LIMA, D. C.; CASTRO, D. P.; LIMA, F. H. C. O Ofidismo e a Formação do Profissional Biólogo no Estado do Ceará. In Vozes da Facedi: reflexões, experiências e perspectivas em educação, edited by A. C. Morais et al. p. 127-140. Editora da UECE: Brazil. 2010. https://www.researchgate.net/publication/309429900.

LUCENA, M. M. A.; FREIRE, E. M. X. Percepção Ambiental como Instrumento de Participação Social na proposição de Área Prioritária para Conservação no Semiárido. INTERthesis, v. 11, p. 147-171, 2014. https://doi.org/10.5007/1807-1384.2014v11n1p147. 
MENDES, B. M. Estudo da Percepção Ambiental de Estudantes: Ferramenta para a Conservação de Serpentes. Revista Presença Geográfica, v. 5, n. 1, p. 36-49, 2018. doi.org/10.36026/rpgeo. v5i1.2640.

MENDONÇA, L. E. T., VIEIRA, W. L. S.; Alves, R. R. N. Caatinga Ethnoherpetology: Relationships between Herpetofauna and People in a Semiarid Region of North-eastern Brazil. Amphibian \& Reptile Conservation, v.8, n. 1, p. 24-78, 2014.

MISE, Y. F; LIRA-DA-SILVA, R. M.; CARVALHO, F. M. Time to Treatment and Severity of Snake Envenoming in Brazil. Revista Panamericana de Salud Pública, v. 42, n. 52, p 1-6, 2018. doi.org/10.26633/RPSP.2018.52.

MOURA, M. R.; et al. O relacionamento entre pessoas e serpentes no leste de Minas Gerais, sudeste do Brasil. Biota Neotrópica, v. 10, n. 4, p. 133-141, 2010. doi.org/10.1590/S167606032010000400018.

NOGAN, H. E.; Haruna, A. "Assessment of Human-Snake Interaction and its outcomes in Monduli District, Northern Tanzania." Tanzania Journal of Health Research, v.17, n. 1, p. 1-12, 2015. doi.org/10.4314/thrb.v17i1.9.

OLIVEIRA, I. S., LUCENA, R. F. P.; FREIRE, E. M. X. Percepção Ambiental de Agricultores de Região Semiárida sobre os Anfíbios Anuros e Biocontrole de Insetos Pragas em Sistemas Irrigados e Não Irrigados, às Margens do Rio São Francisco, Brasil. Gaia Scientia, v. 11, n. 1, p. 269-296, 2017.

PANDEY, D. P.; et al. Public Perceptions of Snakes and Snakebite Management: Implications for Conservation and Human Health in Southern Nepal. Journal of Ethnobiology and Ethnomedicine, v. 12, n. 22, p. 1-24. 2016. doi:10.1186/s13002-016-0092-0.

PINHO, F. M. O.; PEREIRA, I. D. Ofidismo. Revista da Associação Médica Brasileira, v. 47, n.1, p. 24-29, 2001. doi.org/10.1590/S0104-42302001000100026.

PIRES, M. R. S.; PINTO, L. C. L.; FIGUEIREDO, M. R. O. Percepção Ambiental sobre o Conhecimento Popular de Moradores Rurais Relativo as Serpentes e Acidentes Ofídicos. Revistaea, p. 1-8, 2018. http://www.revistaea.org/artigo.php?idartigo $=1615$

PONTES, B. E. S.; et al. Serpentes no Contexto da Educação Básica: Sensibilização Ambiental em uma Escola Pública da Paraíba. Experiências em Ensino de Ciências, v.12, n. 7, p. 79-99, 2017.

PROKOP, P.; TUNNICLIFFE, S. D. 'Disgusting' Animals: Primary School Children's Attitudes and Myths of Bats and Spiders. Eurasia Journal of Mathematics, Science and Technology Education, v.4, n.2, p. 87-97, 2008. doi.org/10.12973/ejmste/75309.

RODRIGUES, M. T. Herpetofauna da Caatinga. In Ecologia e conservação da Caatinga, edited by I. R Leal, M. Tabarelli, and J. M. C. Silva,182-236, Recife, Brazil: Editora Universitária da UFPE, 2003. 
SANDRIN, M. F. N.; PUORTO, G; Nardi, R. Serpentes e Acidentes Ofídicos: um Estudo sobre Erros Conceituais em Livros Didáticos. Investigações em Ensino de Ciências 10 (3): 281-298, 2006.

SANTOS, I. G. C., FORTES-DIAS, C. L. SANTOS, M.C. Aplicações Farmacológicas dos Venenos de Serpentes Brasileiras Enfoque para Crotalus durissus terrificus e Crotalus dusrissus ruruima. Scientia Amazonia, v. 6, n. 1, p. 42-53, 2017. http://scientia-amazonia.org/wp-content/ uploads/2016/10/v6-n1-42-53-2017.pdf.

SANTOS, M. D. S.; LIRA-DA-SILVA, R. M. Rede de Zoologia Interativa: É Possível uma Mudança no Perfil Conceitual de Estudantes do Ensino Médio sobre os Animais Peçonhentos? Gazeta Médica da Bahia, v. 82, n. 1, p. 40-45, 2012.

SEIGEL, R. A.; MULlIN, S. J. Snake Conservation, Present and Future. In Snakes, ecology and conservation, edited by MULLIN, S. J.; SEIGEL R. A., p. 281-90, 2009. Ithaca and London: Comstock Publishing Associates, a Division of Cornell University Press. doi. org/10.7591/9780801459092-015.

SILVA, E. S.; BOCHNER, R; GIMÉNEZ, A. R. M. O Ensino das Principais Características das Serpentes Peçonhentas Brasileiras: Avaliação das Literaturas Didáticas no Ensino Fundamental do Rio de Janeiro. Educar em Revista, v.42, p. 297-316, 2011. doi.org/10.1590/S010440602011000500019.

SILVA, R. P. da. A Escola Enquanto Espaço de Construção do Conhecimento. Revista Espaço Acadêmico, v. 12, n. 139, p. 83-91, 2012. http://www.periodicos.uem.br/ojs/index.php/EspacoAcademico/article/view/17810.

SILVA, T. S.; FREIRE, E. M. X. Perception and use of fauna resources in communities surrounding a conservation unit in northeast Brazil. Acta Scientiarum. Biological Sciences, v. 32, p. 365-371, 2010. 10.4025/actascibiolsci.v32i4.5668

SILVA, J. M. C.; LEAL, I. R.; TABARELLI, M. (editores). Caatinga: The Largest Tropical Dry Forest Region in South America. Cham: Springer, 2017. doi.org/10.1007/978-3-319-68339-3.

SOARES, D. de O.; et al. Como lidar com as serpentes? O Conhecimento Básico e as Atitudes dos Funcionários de uma Universidade no Nordeste do Brasil. Scientia Plena v.10, n.4, p. 1-8, 2014. https://www.scientiaplena.org.br/sp/article/view/1772.

SUDENE - Superintendência do Desenvolvimento no Nordeste. Delimitação do semiárido Rio Grande do Norte, 2017. Accessed February 2019. http://sudene.gov.br/images/arquivos/semiarido/arquivos/riograndedonortedelimitacaosemiarido-dezembro2017.jpeg

TABARELLII, M.; et al. (editores). PELD CNPQ-Dez anos do Programa de Pesquisas Ecológicas de Longa Duração - Achados, Lições e Perspectivas. Recife, Brasil: Editora Universitária da UFPE, 2013.

UHMANN, R. I. M.; ZANON, L. B. Diversificação de Estratégias de Ensino de Ciências na Reconstrução Dialógica da Ação/Reflexão Docente com Foco na Educação Ambiental. Ensaio 
Pesquisa em Educação em Ciências, 15 (3): 163-179, 2013. https://www.scielo.br/pdf/epec/ v15n3/1983-2117-epec-15-03-00163.pdf.

VANZOLINI, P. E.; RAMOS-COSTA, A. M. M.; VITT, L. J. Répteis das Caatingas. Academia Brasileira de Ciencias. Rio de Janeiro. 1 ed. 161p. 1980.

VEllOSO, A. L.; SAMPAIO, E. V. S. B.; PAREYN, F. G. C. Ecorregiões, Propostas para o Bioma Caatinga. Recife, Brasil: Associação Plantas do Nordeste, Instituto de Conservação Ambiental do Brasil, 2002.

WALDEZ, F; VOGT, R. C. Aspectos Ecológicos e Epidemiológicos de Acidentes Ofídicos em Comunidades Ribeirinhas do Baixo Rio Purus, Amazonas, Brasil. Acta Amazonica, v. 39, n. 3, p. 681-692, 2009. doi.org/10.1590/S0044-59672009000300025. 
Mikaelle Kaline Bezerra da Costa

$\checkmark$ mikaellecb@gmail.com

ORCiD: https://orcid.org/0000-0001-7946-4198
Submitted on: 23/07/2020

Accepted on: 24/02/2021

2021;24e:01481

\section{Magnólia Fernandes Florêncio Araújo}

$\checkmark$ magffaraujo@gmail.com

ORCiD: https://orcid.org/0000-0001-8811-7921

\section{Rita Campos*}

$\checkmark$ ritacampos@ces.uc.pt

ORCiD: https://orcid.org/0000-0003-4184-3269

*corresponding author

\section{Eliza Maria Xavier Freire}

$\checkmark$ elizajuju1000@gmail.com

ORCiD: https://orcid.org/0000-0001-9486-6347

How to cite: DA COSTA, M. K. B.; ARAÚJO, M. F. F; CAMPOS, R.; FREIRE, E. M. $\mathrm{X}$. Demystifying ophidism: bridging school and society to develop educational resources. Ambiente $\&$ Sociedade. São Paulo, v. 24, p. 1-22, 2021. 


\title{
Desmitificando o ofidismo: unindo a escola e a sociedade para desenvolver recursos educativos
}

\author{
Mikaelle Kaline Bezerra da Costa \\ Magnólia Fernandes Florêncio Araújo \\ Rita Campos \\ Eliza Maria Xavier Freire
}

São Paulo. Vol. 24, 2021

Artigo Original

\begin{abstract}
Resumo: As escolas são inseparáveis das comunidades, e o aprendizado deve capacitar alunos e comunidades a pensar e agir sobre as questões que os afetam. $\mathrm{Na}$ Caatinga semiárida brasileira, os acidentes ofídicos são um problema de saúde pública. Crenças negativas e um reduzido conhecimento sobre as serpentes geram atitudes negativas, levando a altas frequências de acidentes com estes animais e a problemas de conservação das espécies envolvidas. Assim, questionamos se a elaboração de um conteúdo de educação científica e ambiental usando estratégias didáticas que valorizem os conhecimentos prévios das comunidades locais e informações relacionadas ao contexto poderiam ajudar a superar crenças e reduzir acidentes. A avaliação deste conteúdo mostrou mudanças positivas na percepção sobre serpentes e na aquisição de novos conhecimentos sobre estes animais e ações de prevenção e de pós-acidente, indicando que a estratégia adotada fortaleceu o aprendizado de ciências, contribuindo para a saúde pública e a conservação das serpentes.
\end{abstract}

Palavras-chave: Acidentes ofídicos; percepção; recursos educacionais; educação ambiental; aprendizagem contextualizada.

Como citar: DA COSTA, M. K. B.; ARAÚJO, M. F. F; CAMPOS, R.; FREIRE, E. M. X. Desmitificando o ofidismo: unindo a escola e a sociedade para desenvolver recursos educativos. . Ambiente $\mathbb{\&}$ Sociedade. São Paulo, v. 24, p. 1-22, 2021. 


\title{
Desmitificando el ofidismo: uniendo la escuela y la sociedad para desarrollar recursos educativos
}

\author{
Mikaelle Kaline Bezerra da Costa \\ Magnólia Fernandes Florêncio Araújo \\ Rita Campos \\ Eliza Maria Xavier Freire
}

São Paulo. Vol. 24, 2021

Artículo original
Resumen: Las escuelas son inseparables de las comunidades, y el aprendizaje debe permitir a los estudiantes y a la comunidad pensar y actuar sobre los problemas que les afectan. En la Caatinga semiárida brasileña, los accidentes por mordedura de serpiente son un problema de salud pública. Las creencias negativas y el bajo conocimiento sobre las serpientes generan actitudes negativas, lo que lleva a altas frecuencias de accidentes y problemas de conservación de las especies implicadas. Así, nos preguntamos si el desarrollo de contenidos de educación científica y ambiental utilizando estrategias didácticas que valoran el conocimiento previo de las comunidades locales y la información relacionada con el contexto podría ayudar a superar creencias y reducir los accidentes. La evaluación de este contenido mostró cambios positivos en la percepción de las serpientes y en la adquisición de nuevos conocimientos sobre estos animales y acciones de prevención y post accidente, indicando que la estrategia adoptada fortaleció el aprendizaje científico, contribuyendo a la salud pública y la conservación de serpientes.

Palabras-clave: Accidente de mordedura de serpiente; percepción; recursos educativos; educación ambiental; aprendizaje basado en el contexto.

Como citar: DA COSTA, M. K. B.; ARAÚJO, M. F. F; CAMPOS, R.; FREIRE, E. M. X. Desmitificando el ofidismo: uniendo la escuela y la sociedad para desarrollar recursos educativos. Ambiente $\mathbb{\&}$ Sociedade. São Paulo, v. 24, p. 1-22, 2021. 